\title{
BIOTRANSFORMATION OF A PAPER AND CELLULOSE FACTORY EFFLUENT IN THE PRESENCE OF LACCASE AND HORSERADISH PEROXIDASE
}

\author{
S.M.V. Pacheco; C.H.L. Soares
}

Universidade Federal de Santa Catarina, Departamento de Bioquímica, CP 5079, CEP 88040-970, Florianópolis, SC, Brasil. E-mail: sabrinavillela@yahoo.com.br

\begin{abstract}
The biodegradation of effluent from an industrial paper mill was monitored in relation to the parameters total phenols, low molar mass phenols and color during its incubation with laccase (Novozymes), laccase-HBT and peroxidase (Merck). The results revealed that the laccase reduced the effluent color by $37 \%$ and the peroxidase by $43 \%$. Also, the enzymes had a great efficiency in the reduction of color, total phenols and high molar mass compounds contained in the effluent, indicating that depolymerization occurred.
\end{abstract}

KEY WORDS: Phenolic compounds, lignolytic enzymes, depolymerization.

\section{RESUMO}

BIOTRANSFORMAÇÃO DOS EFLUENTES DE UMA INDÚSTRIA DE PAPEL E CELULOSE NA PRESENÇA DE LACASE E PEROXIDASE. A biodegradação dos efluentes de uma indústria de papel e celulose foi monitorada em relação aos parâmetros de fenóis totais, fenóis de baixa massa molar e cor durante a sua incubação com lacase (Novozymes), lacase-HBT e peroxidase (Merck). Os resultados revelaram que a lacase reduziu a cor do efluente em $37 \%$ e a peroxidase em $43 \%$. Também foi possível observar que as enzimas possuiram grande eficiência na redução de cor, compostos fenólicos totais e compostos fenólicos de alta massa molar contidos no efluente, indicando, desta forma, que a despolimerização ocorreu.

PALAVRAS-CHAVE: Compostos fenólicos, enzimas lignolíticas, despolimerização.

\section{INTRODUCTION}

The paper and cellulose industry produces great volumes of effluents, whose characteristics vary depending on the manufacturing process used. The most toxic effluents are generated in the pulp bleaching stage. Of the pulping (pulp production) technological processes, the most used is that which employs sulfideinalkaline medium, more commonly known as the Kraft process (THOMPSON et al., 2001). The pulp produced by the Kraft process is said to be non-bleached, since a small percentage of lignin remains in it, due to oxidation reactions, and it has a darker color.

The many substances identified in effluents include lignins of low molar mass (MM) and their degradation products, such as: chlorophenols, chololignins, aromatic carboxylic acids, chlorides and non chlorides, and also high molar mass compounds, which can be biotransformed by some organisms, such as fungi and bacteria, especially fungi of the class Basidiomycetes (SOARES; DURÁN, 2001). Several studies have shown that the biotransformation and biodegradation of wood by these fungi depend mainly on their capacity to produce extracellular lignolytic enzymes (HATAKKa, 1994; SOARES; DURÁN, 2001). The most notable lignolytic enzymes producedarelaccasesand peroxidases, belongingtothe phenoloxidases group.

The laccases (1.10.3.2) are produced mainly by fungi and plants. They have molar masses in the region of $60-100 \mathrm{kDa}$, they are generally present in the form of 2 or 3 isoenzymes and they catalyze oxidation reactions through the extraction of one electron of the phenolic substrate generating a phenoxyl radical. However, these enzymes can oxidize nonphenolic compounds in the presence of mediators such as 1-hydroxy-benzotriazole (HBT) (DURÁN et al., 2002; Claus, 2004; Couto; Herrera, 2006; Dwived et al., 2011). The peroxidases (1.11.1.7) can be found in plants and animals (blood plasma, milk, yeasts, etc.). Their molar masses are in the region of 38-43 $\mathrm{kDa}$ and they catalyze the oxidation of phenolic and non-phenolic aromatic compounds (NICELL, 1994). Within this context, the objective of this study was to evaluate the possible chemical modifications caused 
by laccase, laccase in the presence of a mediator and peroxidase in effluent samples from a paper and cellulose factory in Santa Catarina.

\section{MATERIAL E METHODS}

The effluent used was collected from a paper and cellulose factory in Santa Catarina, a producer of non-bleached pulps and had the following physico-chemical characteristics: $\mathrm{pH}$ = 8.1; conductivity $=1.225 \mathrm{mS}$; chemical oxygen demand $(\mathrm{COD})=1,748 \mathrm{mg} / \mathrm{L}$; biological oxygen demand $(B O D)=750 \mathrm{mg} / \mathrm{L}$. The laccase used was donated by Novozymes. The peroxidase and the HBT were acquired from Sigma.

The characterization of the enzymes was carried out through the determination of enzymatic activity and through the determination of MM. The determination of enzymatic activity in different buffers (tartrate $\mathrm{pH}$ : 3.0, 3.5, 4.0, 4.5 and 5.0 and phosphate $\mathrm{pH}: 6.0,6.5,7.0$ and 7.5) were carried out using the method of Eriksson (ANDER; ERIKSSON, 1976). This method is based on the oxidation of syringaldazine to its quinone form which absorbs at $525 \mathrm{~nm}\left(\varepsilon=65000 \mathrm{M}^{-1} \mathrm{~cm}^{1}\right)$. The data were obtained with the aid of a Hewlett-Packard spectrophotometer. The molar mass of each enzyme was determined by High Performance Liquid Chromatography (HPLC), using a Shimadzu chromatograph, equipped with an SPD-10A UV-Vis detector and with a Shimadzu Diol-150 column. The eluent used was Tris $(\mathrm{pH}=$ 9.0) buffer, with a flow of $1 \mathrm{~mL} / \mathrm{min}$. The protein standard used was type MW-GF-200 kit; Sigma.

The decolorization of the effluent was studied through UV-Vis spectrophotometry after the effluent had been submitted to a period of incubation with the enzymes for 45 minutes. The total concentration of low molar mass phenols of the non-treated effluent and effluent treated with enzymes was verified through the 4-aminoantipyrine (4-AAP) method and the total phenol concentrations of the treated and non-treated effluent were verified through the Folin method (American Public..., 1989).

The molar mass distribution analysis of the treated and non-treated effluents was carried out through semi-preparative size-exclusion HPLC, using the equipment cited above. The column used was an Assaypack-Waters and the eluent $\mathrm{H}_{2} \mathrm{O} / 00.5$ $\mathrm{M} \mathrm{NaOH}$, with a flow of $1.0 \mathrm{~mL} / \mathrm{min}$. The effluent samples analyzed were centrifuged at $6400 \mathrm{rpm}$ for 10 minutes. The values for relative content were calculated based on the relation between the areas of each fraction and the total area (sum of the areas of all fractions) measured on each chromatogram. The samples were monitored at the following wavelengths: 240, 280 and $310 \mathrm{~nm}$.

\section{RESULTS AND DISCUSSION}

In relation to the characterization of the enzymes, measurements of the kinetic reaction of the enzymes with syringaldazine in different buffers were initially carried out to determine the best $\mathrm{pH}$ conditions for the activity. The results obtained from the kinetic studies (Fig. 1) showed a better activity at $\mathrm{pH} 4.0$ for both enzymes. The unit of enzyme activity (U) was defined as: the quantity of enzyme necessary to oxidize $1 \mathrm{mM}$ of substrate per second.

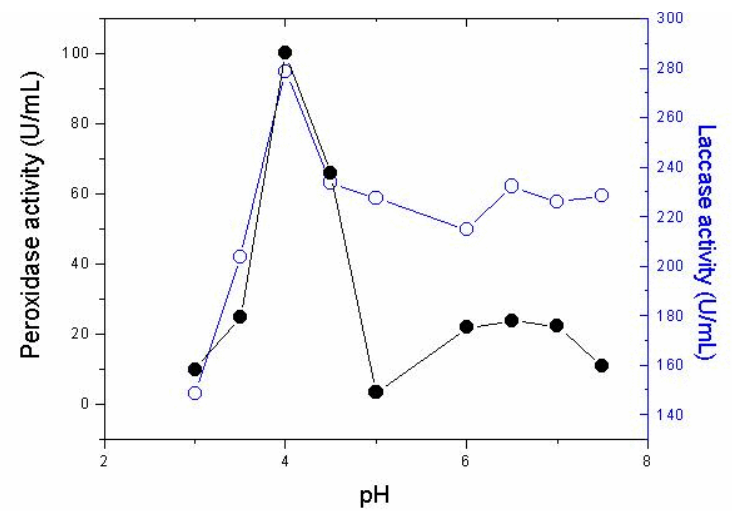

Fig. 1 - Analysis of the enzymatic activity (U/mL) of laccase $(\circ)$ and peroxidase $(\bullet)$ front the different solutions with $\mathrm{pH}(\mathrm{s})$.

The molar mass of each enzyme was determined by HPLC. Through the chromatograms, and comparing with the standard used (MW-GF-200 kit; Sigma), it was observed that the MM of laccase was in the region of $91 \mathrm{kDa}$ and $65 \mathrm{kDa}$ and of peroxidase was $45 \mathrm{kDa}$. All of the results for the characterization of laccase and peroxidase revealed that they have the same characteristics, in relation to the activity $\times \mathrm{pH}$ and molar mass, as the laccases and peroxidases cited in the literature, produced by fungi (HubliK; SCHINNER, 2000; Courteix; Bergel, 1995).

The decolorization of the effluent was monitored through the reduction in absorbance at several wavelengths in the visible-ultraviolet region, after 45 minutes of incubation of the effluent with laccase and peroxidase. A decolorization of the effluent was observed for the two enzymes tested. Laccase was responsible for a decolorization of the effluent of up to $37 \%$ and peroxidase of $43 \%$ (Figs. 2 and 3 ).

After the effluent treatment with laccase, a spectral modification was observed with a shift in the absorption band from $240-270 \mathrm{~nm}$ to $267-310 \mathrm{~nm}$, indicating changes in the structures contained in the effluent. These changes increased proportionally with an increase in laccase concentration. When the same effluent was treated with peroxidase, no type of spectral change was observed, only a reduction in the concentration of total compounds with anincrease in the enzyme concentration, observed through a 
reduction in absorbance in the region of $240-270 \mathrm{~nm}$. Overall, the results obtained revealed that peroxidase was more efficient in the decolorization of the effluents. The peroxidase (HRP) used in this experiment has many similarities with lignin peroxidase (LiP), which is also extensively used in biotechnological applications. Several studies with model substances have revealed that $\mathrm{LiP}$ is able to oxidize both phenolic structures and non-phenolic aromatic structures, showing a great flexibility in relation to the structure of substrates (MARTíNEZ, 2002). In view of the fact that peroxidase has the ability to oxidize a greater variety of compounds than laccase, may leads it to being more efficient in the degradation of effluent compounds and consequently in their decolorization.

Together with the process of effluent decolorization, the concentration of total phenols was measured by two methods, theFolinand the4-aminoantipyridinemethods.

The results obtained using these methods revealed a decrease in the total amount of phenolic compounds in the effluents treated with the two enzymes (Figs. 4 and 5).

The results obtained with the 4-AAP method showed that the two enzymes degrade efficiently the total and low MM phenolic compounds. The fraction of low MMcompounds is that which contains chemical agents responsiblefor the toxicity of the effluents. The

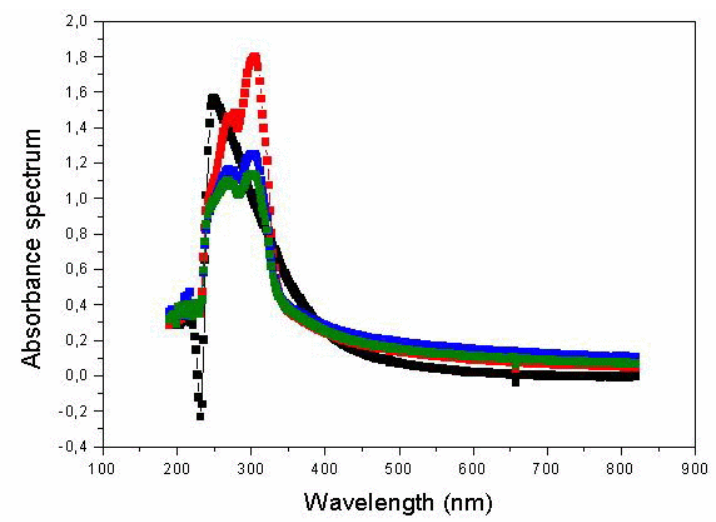

Fig. 2 - Absorbance spectrum of effluent sample before (घ) and after 45 minutes of incubation with $50 \mu \mathrm{L}$ of laccase (घ), $100 \mu \mathrm{L}$ of laccase ( $\mathbf{\square})$ and $150 \mu \mathrm{L}$ of laccase ( $\mathbf{\square})$.

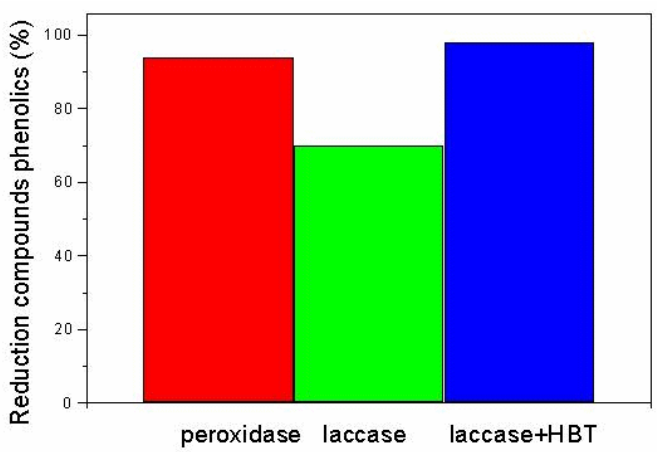

Fig. 4-Total phenol degradation of effluent after 45 minutes of incubation with enzymes. main substances indicated as being of high toxicity are chlorophenols, which are products of the partial degradation of lignin, notably its derivatives: di- and trichloroguaiacol; tri, tetra and pentachlorophenol, and others. Thehigh MMfractions are considered inert and non-toxic, since they are not able to penetrate the cells of living organisms, due to their size. On theother hand, some studies have shown that some of these compounds may be degraded under environmental conditions generating low MM compounds. The high MM phenolic compounds were also efficiently degraded by the enzymes, and particularly by lacasse with HBT. Also, some studies have demonstrated a reduced oxidation capacity of laccase in relation to laccase + HBT or laccase-mediator (CANTORELLA et al., 2003).

The MM distribution analysis of the effluent components, during the period of incubation with the enzymes, indicated that the enzymes cause an intense degradation of the organic material contained in the effluent, as observed by a notable reduction in the total area obtained on the chromatograms measured at 240 and $280 \mathrm{~nm}$ for peroxidase and at 240, 280 and $310 \mathrm{~nm}$ for laccase. From the chromatograms it was possible to obtain a relative concentration of the different compound fractions in relation to molar mass, at the different wavelengths analyzed (Table1).

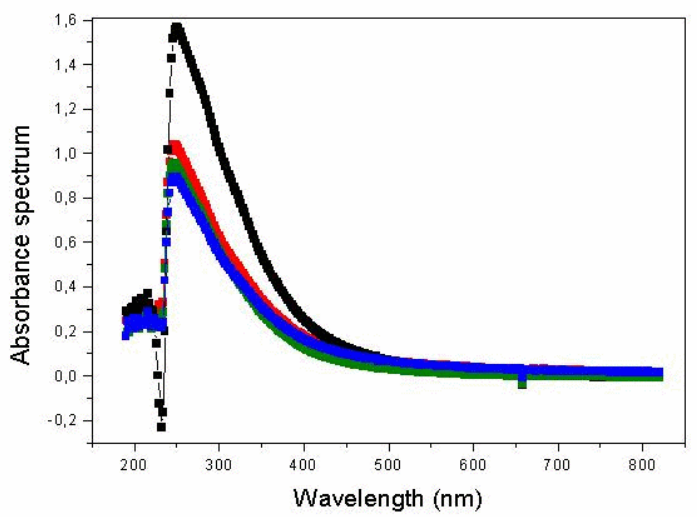

Fig. 3 - Absorbance spectrum of effluent sample before ( $\mathbf{\square}$ ) and after 45 minutes of incubation with $50 \mu \mathrm{L}$ of peroxidase

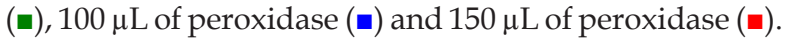

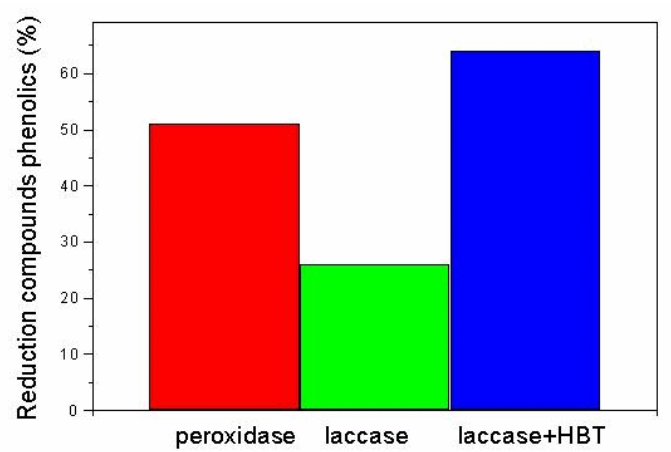

Fig. 5 - Degradation of low MM phenolic compounds of effluent after 45 minutes of incubation with enzymes. 
Table 1 - Relative concentrations (molar mass, MM) of the composite fractions in the effluent obtained by HPLC.

\begin{tabular}{lcccccccc}
\hline & & \multirow{2}{*}{ Effluent } & \multicolumn{4}{c}{$\begin{array}{c}\text { Effluent treated with } \\
\text { laccase + HBT }\end{array}$} & \multicolumn{2}{c}{$\begin{array}{c}\text { Effluent treated with } \\
\text { peroxidase }\end{array}$} \\
\cline { 2 - 9 } & & & \multicolumn{4}{c}{ Relative concentration (\%) } \\
\cline { 2 - 9 } & $240 \mathrm{~nm}$ & $280 \mathrm{~nm}$ & $310 \mathrm{~nm}$ & $240 \mathrm{~nm}$ & $280 \mathrm{~nm}$ & $310 \mathrm{~nm}$ & $240 \mathrm{~nm}$ & $280 \mathrm{~nm}$ \\
\hline High MM & - & 45.5 & - & 11.5 & 16.5 & 10.5 & 4,1 & 1,1 \\
Medium MM & 100 & 54.3 & 100 & 88.5 & 51.5 & 75.2 & 95.8 & 98.9 \\
Low MM & - & - & - & - & 31.7 & 13.5 & - & - \\
\hline
\end{tabular}

${ }^{1}$ Composites of high MM (retention time: 0-11 minutes), composites of average MM (retention time: $12-21$ minutes) and composites of low MM (retention time $>21$ minutes).

Through the results showed in Table 1 it was possible to observe a decrease in the relative concentration of high MM compounds which absorb at $280 \mathrm{~nm}$ after treatment with laccase. Also, low MM compounds appeared which absorb at $310 \mathrm{~nm}$.

For the set of fractions contained in the effluent without treatment, values for Abstotal ${ }_{280} /$ Abstotal $_{310}$ of 7.25 and Abstotal $_{280} /$ Abstotal $_{240}$ of 1.95 were observed, revealing a greater number of compounds which absorb in the $280 \mathrm{~nm}$ region than in the 310 $\mathrm{nm}$ or $240 \mathrm{~nm}$ regions.

The fractions contained in the effluent after treatment with laccase gave values for $\mathrm{Abstotal}_{280} /$ Abstotal $_{310}$ of 2 and Abstotal $_{280} /$ Abstotal $_{240}$ of 0.72 , which indicates a shift in the absorption of these compounds, possible due to structural changes. Therefore, the results obtained with the chromatograms are in agreement with the results obtained through the UV-Vis spectra and showed that laccase $+\mathrm{HBT}$ act on the effluent, depolymerizing high MM compounds.

The fractions contained in the effluent after treatment with peroxidase, had a value for $\mathrm{Atotal}_{280}$ / Atotal $_{240}$ of 0.24 , which indicates a greater quantity of compounds which absorb in the $240 \mathrm{~nm}$ region in relation to laccase which had a value for Atotal $_{280} /$ Atotal $_{240}$ of 0.72 . Through Table 1 it is possible to observe that the non-treated effluent (monitored at 240 and $280 \mathrm{~nm}$ ) contained a great quantity of medium MM compounds. After treatment with peroxidase this value remained almost unchanged. The fraction of medium MM compounds, which appear to remain unchanged, may suffer structural modifications, as indicated by the different percentages, when monitored at different wavelengths, as shown in Table 1.

\section{CONCLUSIONS}

The enzymes laccase and peroxidase showed a great efficiency in the reduction of color, total phenols and consequently of high MMcompounds contained in the effluent, indicating that a depolymerization of the compounds occurred. Therefore, the use of enzymes in the procedures for the bioremediation of industrial effluents is shown to be an attractive alternative, mainly due to the good results obtained.

\section{ACKNOWLEDGEMENTS}

The authors are grateful to Novozymes for donating the laccase and to $\mathrm{CNPq}$ for financial support provided to carry out the project.

\section{REFERENCES}

ANDER, P.; ERIKSSON, K. The importance of phenol oxidase activity in lignin degradation by the white-rot fungus Sporotrichum pulverulentum. Archives of Microbiology, v. 109, p.1-8, 1976.

\section{AMERICAN PUBLIC HEALTH ASSOCIATION.}

American Water Works Association. Standard Methods for examination of water and wasterwater 550B. 17.ed. New York: American Public Health Association, 1989.

\section{CANTORELLA, G., GALLI, C.; GENTILI, P. Free} radical versus electron-transfer routes of oxidation of hydrocarbons by Laccase/Mediator systens - catalytic or stoichiometric procedures. Journal of Molecular Catalysis, v.863, p.1-10, 2003.

CLAUS. H. Laccases: structure, reactions, distribution. Mícron, v.35, n.1, p.93-96, 2004.

COURTEIX, A.; BERGEL. A. Horse-Radish peroxidase catalyzed hydroxylation of phenol II. Kinetic Model. Enzyme and Microbiol Technology, v.17, p.1087-1093, 1995.

COUTO, S.R.; HERRERA, J.L.T. Industrial and Biotechnological applications of laccases: A review. Biotechnology Advances, v. 24, p. 500-513, 2006.

DURAN, N.; ROSA, M.A.; D'ANNIBALE GIANFREDA, L. Aplications of Laccase and Tyrosinases (phenoloxidases) immobilized on different supports: a review. Enzyme and Microbiol Technology, v. 31, p. 907-931, 2002.

DWIVED, U.N.; PRIYANKA, S.; PANDEY, V.P.; KUMAR, A. Structure-function relationship among 
bacterial, fungal and plant laccases. Journal of Molecular Catalysis B: Enzymatic, v.68, p.117-118, 2011.

HATAKKA, A. Lignin-modifying enzymes from selected white-rot fungi: production and role from in lignin degradation. FEMS Microbiology Reviews, v.13, n.2, p.125-135, 1994.

HUBLIK, G.; SCHINNER, F. Characterization and immobilization of the laccase from Pleurotus ostreatus and its use for the continuous elimination of phenolic polluants. Enzyme and Microbial Technology, v.27, p.330336, 2000.

MARTÍNEZ, A.T. Molecular biology and structurefunction of lignin-degrading heme peroxidases Review. Enzyme and Microbiol Technology, v.30, n.4, p.425-444, 2002.
NICELL, J.A. Kinetics of Horseradish PeroxidaseCatalysed Polymerization and Precipitation of Aqueous 4-Chlorophenol. Journal of Chemical Technology and Biotechnology, v.60, p.203-215, 1994.

SOARES, C.H.L.; DURÁN, N. Biodegradation of chlorolignin and lignin like contained in E1 pulp bleaching effluent by fungal treatment. Applied Biochemical and Biotechnology, v.95, p.135-149, 2001.

THOMPSON, G.; SWAN, J.; KAY, M.; FORSTER, C.F. The treatment of pulp and paper mill effluent: a review. Bioresouce Technology, v.77, n.3, p.275-286, 2001.

Received on $24 / 5 / 08$

Accepted on 5/8/11 